\title{
LAND TENURE SYSTEM DALAM MELINDUNGI LAHAN PERTANIAN PANGAN BERKELANJUTAN DAN KEDUDUKANNYA DALAM HUKUM AGRARIA NASIONAL
}

\author{
Anita Kamilah \\ Dosen Program Magister Ilmu Hukum dan Dosen Fakultas Hukum \\ Universitas Suryakancana \\ E-mail: anita.kamilah@yahoo.co.id \\ Yuyun Yulianah \\ Dosen Fakultas Hukum Universitas Suryakancana \\ E-mail: yuyunyuliana01@gmail.com
}

\begin{abstract}
ABSTRAK
Seiring dengan peningkatan jumlah penduduk dan perkembangan struktur perekonomian, kebutuhan lahan untuk kegiatan non pertanian cenderung terus meningkat. Kecenderungan tersebut menyebabkan alih fungsi lahan pertanian khususnya tanah sawah yang sulit dihindari. Faktor-faktor penyebab alih fungsi lahan pertanian yaitu faktor: (1) Kependudukan; (2) Kebutuhan lahan nonpertanian; (3) Ekonomi; (4) Sosial budaya; (5) Otonomi Daerah; dan (6) Lemahnya peraturan perundang-undangan. Dampak alih fungsi lahan pertanian selain dapat mengakibatkan ancaman terhadap ketahanan pangan, juga akan mengganggu terhadap stabilitas ekonomi, sosial, politik, dan perkembangan penduduk secara umum. Kebijakan untuk mengendalikan alih fungsi lahan dapat dilakukan melalui tiga cara, yaitu: (1) Regulation; (2) Acquisition and management, yaitu menyempurnakan sistem dan aturan jual beli lahan serta penyempurnaan pola penguasaan lahan (Land Tenure System) yang ada guna mendukung upaya ke arah mempertahankan keberadaan lahan pertanian; serta (3) Incentive and charges.
\end{abstract}

Kata kunci: Alih Fungsi Lahan, Ketahanan Pangan, Land Tenure System.

\begin{abstract}
By the increasing of the population and the economic structural development, the need of land for non-agricultural activities are likely to rise. This phenomenon leads a conversion of agricultural land, especially the unavoidable paddy. The causative factors of agricultural land conversion are: (1) Population; (2) The need of nonagricultural soil; (3) Economy; (4) Socio-cultural; (5) Autonomous Region; and (6) Lack of regulation. The Impacts of this conversion not only threatening food security but also interfering the stability of the economy, social, political, and development of the general population. There are three ways in controlling the use of land, they are: (1) Regulation; (2) Acquisition and management, those are perfecting the system and rules of land selling and the perfection of land tenure patterns (Land Tenure system) in supporting efforts towards maintaining agricultural land; and (3) Incentive and charges.
\end{abstract}

Keywords: Agricultural land conversion, Food Security, Land Tenure System 


\section{PENDAHULUAN}

Seiring dengan peningkatan jumlah penduduk dan perkembangan struktur perekonomian, kebutuhan lahan untuk kegiatan non pertanian cenderung terus meningkat. Kecenderungan tersebut menyebabkan alih fungsi lahan pertanian khususnya tanah sawah sulit dihindari. Masalah alih fungsi lahan pertanian pangan, terutama lahan sawah telah berlangsung sejak dasawarsa 90 -an. Pada periode tahun 1981-1999 tercatat neraca pertambahan lahan sawah seluas 1,6 juta ha, namun antara Tahun 1999-2002 terjadi penciutan lahan seluas 0,4 juta ha atau 141.285 ha per Tahun. Bahkan dalam Rencana Strategis Kementerian Pertanian Tahun 2010-2014, diungkapkan bahwa terjadi konversi lahan sawah menjadi lahan non pertanian dari Tahun 1999-2002 mencapai 563.159 ha atau 187.719,70 ha per Tahun. Data BPS Tahun 2004 menunjukkan bahwa besaran laju alih fungsi lahan pertanian dari lahan sawah ke non sawah seluas 187.720 ha per Tahun dengan rincian alih fungsi ke non pertanian seluas 110.164 ha per Tahun dan alih fungsi ke pertanian lainnya sebesar 77.556 ha per Tahun. Adapun alih fungsi lahan kering pertanian ke non pertanian seluas 9.152 ha per Tahun. Berdasarkan sintesis data dan informasi dari sejumlah hasil penelitian dan data yang dipublikasikan oleh sejumlah instansi terkait, diperkirakan luas lahan sawah yang terkonversi tidak kurang dari 150.000 ha per Tahun. Namun demikian, sampai saat ini belum ada data yang akurat tentang besaran alih fungsi lahan sawah tersebut. Hal ini terkait dengan pemantauan dan pencatatannya yang belum terlembagakan dengan baik. Berdasarkan hasil sensus lahan yang dilakukan oleh Kementerian Pertanian pada Tahun 2010, terjadi penyusutan lahan menjadi3,5 juta ha dari luas lahan sawah 4,1 juta ha pada Tahun 2007, dalam rentang waktu tiga Tahun, konversi lahan mencapai 600.000 ha". 1

Beberapa kasus menunjukkan jika di suatu lokasi terjadi alih fungsi lahan, maka dalam waktu yang tidak lama lahan di sekitarnya juga beralih fungsi secara progresif. Hal tersebut terjadi di Kabupaten Sukabumi, juga pada kabupaten tetangganya yaitu Cianjur. Kasus di Kabupaten Sukabumi terjadi penyusutan luas lahan sawah sebesar 5.162 ha, (lima ribu seratus enam puluh

\footnotetext{
1 Nana Apriyana, Kebijakan Pengendalian Konversi Lahan Pertanian Dalam Rangka Mempertahankan Ketahanan Pangan nasional, Studi kasus pulau Jawa, Kementerian Perencanaan Pembangunan Nasional/Badan Perencana Pembangunan Nasional, Jakarta, 2010, hlm. 50.
} 
dua hektar) pada periode Tahun 20082010 atau terjadi konversi lahan sawah seluas 1.720,67 ha (seribu tujuh ratus dua puluh koma enam puluh juta hektar), per Tahun. Begitu pula luas lahan kering pertanian periode 2008-2010 mengalami penyusutan seluas 6.910 ha (enam ribu sembilan ratus sepuluh hektar) atau terjadi konversi lahan kering seluas 2.303,33 (dua ribu tiga ratus tiga puluh tiga hektar), ha per Tahun. Sebaliknya penggunaan lahan untuk bangunan dan lahan sekitar meningkat seluas 2.392 ha pada periode 2008-2010 atau terjadi eskalasi lahan seluas 797,33 ha setiap Tahunnya. Hasil survey lokasi di15 Kecamatan dan 25 Desa memperlihatkan luas alih fungsi lahan mencapai 810,27 ha atau $22,18 \%$ dari lahan baku pertanian pangan seluas $3.563,11$ ha". 2

Faktor-faktor yang menyebabkan alih fungsi lahan pertanian yaitu: Pertama, sejalan dengan pembangunan kawasan perumahan atau industri di suatu lokasi alih fungsi lahan, maka aksesibilitas dilokasi tersebut menjadi semakin kondusif untuk pengembangan industri dan pemukiman yang akhirnya mendorong meningkatnya permintaan

2 Wan. A. Hirawan, Kajian Hukum Normatif dan Sosiologi Pembentukan Dinas Pertanahan Kabupaten Sukabumi, Badan Pendidikan dan Pelatihan Pemerintah Kabupaten Sukabumi, 2006, hlm. 19. lahan oleh investor lain atau spekulan tanah sehingga harga lahan di sekitarnya meningkat. Kedua, peningkatan harga lahan selanjutnya dapat mendorong petani lain di sekitarnya untuk menjual lahan. ${ }^{3}$

Dampak alih fungsi lahan dari lahan pertanian ke lahan non pertanian khususnya lahan sawah mengakibatkan kehilangan produksi pangan beras, sebagai contoh jika rata-rata konversi lahan sawah setiap Tahun 100.000 ha, kemudian jika capaian hasil per ha sebesar 5,10 ton maka alih fungsi lahan sawah akan mengakibatkan kehilangan produksi pangan beras sebesar 51.000 ton setiap Tahun. Ancaman terhadap ketahanan pangan ini tidak hanya menyebabkan berkurangnya produksi beras, tetapi juga akan mengganggu terhadap stabilitas ekonomi, sosial masyarakat, politik, dan perkembangan penduduk secara umum. ${ }^{4}$

Secara yuridis normatif cukup banyak kebijakan yang berkaitan dengan masalah pengendalian alih fungsi lahan pertanian, salah satu diantaranya Undang-Undang Nomor 41 Tahun 2009 tentang Perlindungan Lahan Pertanian

3 Wan. A. Hirawan, Kajian Hukum Normatif... Ibid, hlm. 19.

4 Wan. A. Hirawan, Kajian Hukum Normatif... Ibid, hlm. 19. 
Pangan Berkelanjutan. Akan tetapi, hingga kini implementasinya belum berhasil diwujudkan secara optimal. Sehubungan dengan itu, mengingat dampak serius dari alih fungsi lahan pertanian, maka diperlukan kebijakan alternatif yang mencakup komponen instrumen hukum dan ekonomi, zonase dan insentif masyarakat, serta formulasi alternatif model perlindungan lahan pertanian pagan berkelanjutan melalui pendekatan penyempurnaan sistem aturan jual beli lahan serta pola penguasaan lahan (Land Tenure System).

Berdasarkan latar belakang yang telah diuraikan pada bagian sebelumnya, maka permasalahan-permasalahan yang diteliti dapat dirumuskan sebagai berikut:

1. Bagaimanakah implementasi konsep land tenure system dalam melindungi lahan pertanian pangan berkelanjutan?

2. Bagaimanakah ketentuan hukum agraria nasional mengatur mengenai konsep land tenure system?

3. Bagaimanakah hak dan kewajiban pihak-pihak yang terkait dengan perlindungan lahan pertanian pangan berkelanjutan melalui model land tenure system?

\section{HASIL PENELITIAN DAN ANALISIS}

\section{A. Implementasi Konsep Land Tenure System dalam Melindungi Lahan Pertanian Pangan Berkelanjutan}

Isu penting dalam pembangunan dewasa ini adalah pertanian berkelanjutan. Seiring dengan laju konversi lahan pertanian, sumberdaya pertanian yang perlu mendapatkan prioritas adalah lahan pertanian, terutama lahan pertanian pangan. Untuk mengendalikan konversi lahan pertanian ke non pertanian, telah diterbitkan Undang-Undang RI Nomor 41 Tahun 2009 tentang Perlindungan Lahan Pertanian Pangan Berkelanjutan.

Mengadopsi definisi pembangunan berkelanjutan dari Word Commission on Environment and Development (WCED), pembangunan berkelanjutan adalah pembangunan yang diorientasikan untuk memenuhi kebutuhan generasi sekarang tanpa mengorbankan kemampuan generasi yang akan datang untuk memenuhi kebutuhan masyarakat. Terdapat empat prinsip yang harus dipenuhi, untuk mencapai tujuan pembangunan berkelanjutan yaitu pemenuhan kebutuhan dasar, memelihara integritas ekologi, keadilan sosial dan kesempatan menentukan nasib sendiri. 
Berdasarkan definisi pembangunan berkelanjutan dari WCED, Organisasi Pangan Dunia mendefinisikan pertanian berkelanjutan sebagai manajemen dan konservasi basis sumberdaya alam, dan orientasi perubahan teknologi dan kelembagaan guna menjamin tercapainya dan terpuaskannya kebutuhan manusia generasi saat ini maupun mendatang. Pembangunan pertanian berkelanjutan mengkonservasi lahan, air, sumberdaya genetik tanaman maupun hewan, tidak merusak lingkungan, tepat guna secara teknis, layak secara ekonomis, dan diterima secara sosial. ${ }^{5}$

Lahan merupakan kesatuan berbagai sumberdaya daratan yang saling berinteraksi membentuk suatu sistem struktural dan fungsional. Sumberdaya lahan dapat mengalami perubahan karena aktivitas manusia. Penggunaan lahan (land use) adalah setiap bentuk campur tangan (intervensi) manusia terhadap lahan dalam rangka memenuhi kebutuhan hidupnya, baik material maupun spiritual. Penggunaan lahan dapat dikelompokkan ke dalam dua kelompok besar yaitu (1) penggunaan lahan pertanian dan (2) penggunaan lahan bukan pertanian.

5 FAO., Sustainable Development and Natural Resources Management. Twenty-Fifth Conference, Paper C 89/2 simp 2, Food and Agriculture Organization, Rome, 1989.
Konversi lahan adalah perubahan fungsi sebagian atau seluruh kawasan lahan dari fungsinya semula (seperti yang direncanakan) menjadi fungsi lain yang menjadi dampak negatif (masalah) terhadap lingkungan dan potensi lahan. Konversi lahan juga dapat diartikan sebagai perubahan untuk penggunaan lain disebabkan oleh faktor-faktor yang secara garis besar meliputi keperluan untuk memenuhi kebutuhan penduduk yang makin bertambah jumlahnya dan meningkatnya tuntutan akan mutu kehidupan yang lebih baik. ${ }^{6}$

Konversi lahan merupakan suatu akibat adanya pertumbuhan ekonomi dan pertambahan jumlah penduduk yang terus meningkat. Menurut Rustiadi dan Reti, hal tersebut tercermin dari: (1) pertumbuhan aktivitas pemanfaatan sumberdaya alam akibat meningkatnya permintaan kebutuhan terhadap penggunaan lahan, (2) adanya pergeseran kontribusi sektor-sektor pembangunan primer, khususnya dari sektor pertanian dan pengolahan sumberdaya ke sektor sekunder (manufaktur) dan sektor tersier (jasa). Dalam hukum ekonomi pasar, alih

6 Rustiadi, E dan W. Reti, Urgensi Lahan Pertanian Pangan Abadi dalam Perspektif Ketahanan Pangan, dalam Arsyad, S dan E. Rustiadi (Ed), Penyelamatan Tanah, Air dan Lingkungan. Crestpent Press dan Yayasan Obor Indonesia, 2008, hlm. 61-86. 
fungsi lahan berlangsung dari aktivitas yang land rent nya rendah ke aktivitas yang land rent nya tinggi. Land rent adalah nilai keuntungan bersih dari aktivitas pemanfaatan lahan per satuan luas lahan dan waktu tertentu. ${ }^{7}$

Secara komprehensif, Iwan Isa, menjelaskan faktor-faktor yang mempengaruhi alih fungsi lahan pertanian sebagai berikut:

1. Faktor kependudukan, yakni pesatnya peningkatan jumlah penduduk telah meningkatkan permintaan tanah untuk perumahan, jasa, industri, dan fasilitas umum lainnya. Selain itu, peningkatan taraf hidup masyarakat juga turut berperan menciptakan tambahan permintaan lahan akibat peningkatan intensitas kegiatan masyarakat seperti lapangan golf, pusat perbelanjaan, jalan tol, tempat rekreasi, dan sarana lainnya.

2. Kebutuhan lahan untuk kegiatan nonpertanian antara lain pembangunan real estate, kawasan industri, kawasan perdagangan, dan jasa-jasa lainnya yang memerlukan lahan yang luas, sebagian diantaranya berasal dari lahan pertanian termasuk sawah. Hal ini dapat dimengerti, mengingat

7 Rustiadi, E dan W. Reti, Urgensi Lahan Pertanian... Ibid., hlm. 61-86. lokasinya dipilih sedemikian rupa sehingga dekat dengan pengguna jasa yang terkonsentrasi di perkotaan dan di wilayah sekitarnya (sub urban area). Lokasi sekitar kota yang sebelumnya didominasi oleh pengguna lahan pertanian, menjadi sasaran kegiatan pengembangan kegiatan non pertanian mengingat harganya yang relatif murah serta telah dilengkapi dengan sarana dan prasarana penunjang seperti jalan raya, listrik, telepon, air bersih, dan fasilitas lainnya. Selain itu, terdapat keberadaan "sawah terjepit" yakni sawah-sawah yang tidak terlalu luas karena daerah sekitarnya sudah beralih menjadi perumahan atau kawasan industri, sehingga petani pada lahan tersebut mengalami kesulitan mendapatkan air, tenaga kerja, dan sarana produksi lainnya, yang memaksa pemilik tanah untuk mengalihkan atau menjual tanahnya.

3. Faktor ekonomi, yaitu tingginya lend rent yang diperoleh oleh aktivitas sektor non-pertanian dibandingkan dengan sektor pertanian. Rendahnya insentif untuk berusaha tani disebabkan oleh tingginya biaya produksi, sementara harga hasil pertanian relatif rendah dan fluktuasi. 
Selain itu, karena faktor kebutuhan keluarga petani yang terdesak oleh kebutuhan modal usaha atau keperluan keluarga lainnya (pendidikan, mencari pekerjaan non pertanian, atau lainnya), seringkali membuat petani tidak mempunyai pilihan selain menjual sebagian lahan pertaniannya.

4. Faktor sosial budaya, antara lain keberdayaan hukum waris yang menyebabkan terfragmentasinya tanah pertanian, sehingga tidak memenuhi batas minimum skala usaha ekonomi yang menguntungkan.

5. Degradasi lingkungan, antara lain kemarau panjang yang menimbulkan kekurangan air untuk pertanian terutama sawah; penggunaan pupuk dan pestisida secara berlebihan yang berdampak pada serangan hama tertentu akibat musnahnya predator alami dari hama yang bersangkutan, serta pencemaran air irigasi; rusaknya lingkungan sawah sekitar pantai mengakibatkan terjadinya instruksi (penyusupan) air laut ke daratan yang berpotensi meracuni tanaman padi.

6. Otonomi daerah yang mengutamakan pembangunan pada sektor menjanjikan keuntungan jangka pendek lebih tinggi guna meningkatkan Pendapatan Asli Daerah (PAD), yang kurang memperhatikan kepentingan jangka panjang dan kepentingan nasional yang sebenarnya penting bagi masyarakat secara keseluruhan.

7. Lemahnya sistem Perundangundangan dan penegakan hukum (Law Enforcement) dari peraturan-peraturan yang ada". 8

Selain itu, menurut Irawan, Konversi lahan pada dasarnya terjadi akibat adanya persaingan dalam pemanfaatan lahan antara sektor pertanian dan sektor non pertanian, sedangkan persaingan dalam pemanfaatan lahan tersebut muncul akibat adanya tiga fenomena ekonomi dan sosial, yaitu 1) keterbatasan sumberdaya lahan, 2) pertumbuhan penduduk dan 3) pertumbuhan ekonomi. Luas lahan yang tersedia relatif terbatas, sehingga pertumbuhan penduduk akan meningkatkan kelangkaan lahan yang dapat dialokasikan untuk kegiatan pertanian dan non pertanian. ${ }^{9}$ Sementara itu, pertumbuhan ekonomi cenderung mendorong permintaan lahan untuk kegiatan non pertanian pada laju lebih tinggi dibanding permintaan lahan untuk

8 Wan. A. Hirawan, Kajian Hukum Normatif... Op Cit, hlm. 71.

9 Irawan, B., Konversi Lahan Sawah: Potensi Dampak, Pola Pemanfaatannya dan Faktor Determinan, Jurnal Forum Penelitian Agro Ekonomi, 2005, hlm. 1-18. 
kegiatan pertanian karena permintaan produk non pertanian lebih elastis terhadap pendapatan. Meningkatnya kelangkaan lahan akibat pertumbuhan penduduk, yang diikuti dengan meningkatkan permintaan lahan yang relatif tinggi untuk kegiatan non pertanian akibat pertumbuhan ekonomi, pada akhirnya menyebabkan terjadinya konversi lahan pertanian.

Alih fungsi lahan dari lahan pertanian ke lahan non pertanian khususnya lahan sawah akan mempengaruhi tiga variabel penting dalam produksi yaitu luas tanam, luas panen, dan jumlah produksi. Jika hasil per ha sudah mencapai titik optimum maka akan terjadi penurunan produksi pangan.

Apriyana mengemukakan dampak alih fungsi lahan sawah sebagai berikut:

"Ketahanan pangan dipengaruhi oleh semakin maraknya konversi lahan sawah, dan pengaruhnya sangat signifikan. Rataan konversi lahan sawah setiap Tahun 100.000 ha. Jika capaian hasil per ha sebesar 5,10 ton maka alih fungsi lahan sawah akan mengakibatkan kehilangan produksi pangan beras sebesar 51.000 ton setiap Tahun. Banyak daerah perkotaan yang sebelumnya merupakan daerah swasembada pangan beras, kemudian berubah menjadi daerah yang mengimpor beras dari daerahdaerah lainnya. ${ }^{10}$

\section{Menurut Sumaryanto dan Suhaeti} dalam Nurmanaf et al, dampak konversi lahan dari aspek sosial ekonomi adalah kehilangan produksi pertanian dan nilai tambahnya, berkurangnya pendapatan dari sektor pertanian, hilangnya kesempatan kerja pertanian dan pendapatan kerja yang dihasilkannya, tidak berfungsinya irigasi yang telah dibangun dengan biaya besar, timbulnya pencemaran dan degradasi lingkungan, dan hancurnya beberapa kelembagaan lokal yang selama ini menunjang pembangunan pertanian. Sementara itu, manfaat ekonomi yang diperoleh tidak memadai khususnya bagi masyarakat setempat. ${ }^{11}$

Menyikapi berbagai persoalan tentang alih fungsi lahan pertanian tersebut, Pearce dan Turner dalam Iqbal dan Sumaryanto, mengemukakan beberapa metode pengendalian alih fungsi lahan, diantaranya melalui Land Tenure System, yaitu salah satu cara pengendalian alih fungsi lahan pertanian

10 Nana Apriyana, Kebijakan Pengendalian Konversi Lahan Pertanian, Loc It.

11 Nurmanaf, A.R, H. Mayrowani, dan E. Jamal, Evaluasi Sosial Ekonomi Multifungsi Lahan Sawah. Prosiding Seminar Nasional Multifungsi Lahan Sawah, 2001, hlm. 121136. 
yang dilakukan oleh pihak yang memiliki kewenangan melalui penyempurnaan sistem aturan jual beli lahan serta pola penguasaan lahan yang ada guna mendukung upaya ke arah mempertahankan keberadaan lahan pertanian. ${ }^{12}$

\section{Metode Land Tenure System} sebagai salah satu strategi yang dapat dilakukan pemerintah guna mencegah alih fungsi lahan pertanian dengan mengikutsertakan partisipasi masyarakat. Namun demikian, keberhasilan penggunaan metode Land Tenure System tidak dapat dijalankan secara sendiri, tetapi harus didukung oleh metodemetode lainnya yaitu metode Regulation dan Incentive and charges.

Metode Regulation, adalah suatu cara pencegahan alih fungsi lahan pertanian, dimana pengambil kebijakan menetapkan sejumlah aturan dalam pemanfaatan lahan yang ada. Berdasarkan pertimbangan teknis, ekonomis, dan sosial, pengambil kebijakan melakukan pewilayahan (zoning) terhadap lahan yang ada serta kemungkinan bagi proses alih fungsi, melalui mekanisme perizinan yang jelas dan transparan dengan melibatkan semua pemangku

12 Muhammad Iqbal, dan Sumaryanto, Strategi Pengalihan alih Fungsi Lahan Pertanian Bertumpu Pada Partisipasi Masyarakat, Pusat Analisis Ekonomi dan Kebijakan Pertanian, Jakarta, 2007, hlm. 173. kepentingan yang ada dalam proses alih fungsi lahan. ${ }^{13}$

Adapun yang dimaksud dengan incentive and charges adalah pemberian subsidi atau insentif yang diberikan pemerintah kepada para petani yang dapat meningkatkan kualitas lahan yang dimilikinya, serta pemberian insentif pajak yang menarik bagi petani yang mempertahankan keberadaan lahan pertaniannya, serta memberikan sarana dan prasarana yang mendukung peningkatan hasil pertaniannya. ${ }^{14}$

\section{A. Kedudukan Land Tenure System}

\section{Dalam Hukum Agraria Nasional}

"Land tenure system", merupakan istilah Inggris yang diterjemahkan secara umum sebagai sistem penguasaan tanah. Menurut Bruce dalam review of tenure terminology, istilah "tenure" berasal dari jaman feodal Inggris, dimana setelah bangsa Normandia menduduki Inggris sekitar tahun 1066, terjadi penghapusan hak-hak masyarakat atas tanahnya, dan mengganti hak tersebut sebagai

13 Muhammad Iqbal, dan Sumaryanto, Strategi Pengalihan... Ibid., hlm. 173.

14 Muhammad Iqbal, dan Sumaryanto, Strategi Pengalihan... Ibid., hlm. 173. 
pemberian grant (bantuan) dari pemerintahan baru. ${ }^{15}$

Beberapa sumber menjelaskan pula bahwa kata tenure berasal dari bahasa Latin "tenere" yang mencakup arti: memelihara, memegang, memiliki. Land tenure berarti sesuatu yang dipegang dalam hal ini termasuk hak dan kewajiban dari pemangku lahan ("holding or possessing" sama dengan pemangkuan atau penguasaan). Land tenure adalah istilah legal untuk hak pemangkuan lahan, dan bukan hanya sekedar fakta pemangkuan lahan, karena seseorang mungkin memangku lahan, tetapi tidak selalu mempunyai hak menguasai. ${ }^{16}$

Oleh karena itu, tenure bukan hanya pengertian pemilikan terhadap sesuatu atau terhadap tanah, tetapi mencakup:

1. Hak pakai (access), Fasilitas untuk memanfaatkan lahan atau sumberdaya lain.

2. Hak mengawasi (control), dan

3. Hak memiliki (Ownership) baik terhadap, tanaman, hewan ternak, dan air.

15 Bruce, JW., Review of tenure terminology. Tenure Brief No. 1. University of WisconsinMadison. USA, 1998.

16 Bruce, JW., Review of tenure terminology.... Ibid.
4. Struktur agraria (Agrarian structure): Pola distribusi lahan.

5. Perubahan agraria (Agrarian reform): upaya untuk mengubah struktur agraria yang meliputi antara lain land reform, land tenure reform, dan perubahan lain yang mendukung.

6. Tenure reform diterjemahkan sebagai perubahan pemangkuan secara legal yang dilakukan oleh pemerintah maupun masyarakat lokal. Tenure reform berbeda dengan land reform. Land reform mencakup pendistribusian ulang pemangkuan lahan dan akan mengubah sistem agraria, sementara tenure reform tidak mengubah pemangku lahan namun hanya mengubah hakhaknya.

7. Common: lahan atau sumberdaya alam lain yang digunakan secara terus menerus oleh anggota masyarakat.

8. Common property: sebuah "common" dimana hanya masyarakat anggota yang dapat memanfaatkannya dan terdapat pengawasan penggunaan.

9. Common property institution: sebuah organisasi yang mengelola "common property", atau hak 
pengelolaan "common property" itu sendiri.

10. Private property: aset yang dimiliki oleh swasta/non pemerintah (pribadi maupun kelompok).

11. Public property: aset yang dikuasai oleh pemerintah.

Sebagaimana disebutkan di atas, bahwa dalam pemahaman "tenure", dikenal pula istilah "common property". Istilah "common" berarti sebuah area dimana seluruh pemangku lahan dalam suatu wilayah mempunyai hak untuk melakukan aktivitas seperti mengambil rumput dan mengumpulkan kayu. Menurut sejarah, ini bukan sebuah bentuk kepemilikan namun sebuah pola jaminan penggunaan secara sah dimana seluruh anggota secara bebas boleh menggunakan tanah secara simultan. ${ }^{17}$

Berkaitan dengan "common" ini, pada tahun 1968 Garret Hardin memperkenalkan konsep tentang "sebuah tragedi yang terjadi terhadap common", karena ada pemanfaatan sumber daya alam yang melebihi kapasitas, sehingga menyebabkan kerusakan sumber daya alam yang tidak terkendali.

Merespon pendapat Garret Hardin tersebut, beberapa ahli ekonomi sumberdaya alam dan yang lainnya

\footnotetext{
${ }^{17}$ Bruce, JW., Review of tenure terminology. Ibid.
}

berpendapat bahwa pada “common" area pemanfaatannya dibatasi hanya untuk anggota masyarakat yang mempunyai hak terhadap area tersebut. Selain itu, beberapa area "common" memiliki pembatasan penggunaan (seperti pembatasan musim untuk pengambilan rumput, pembatasan tipe pakan ternak yang dapat diambil, dan lain-lain).

Kemudian, ada perbedaan baru yang dibangun dari istilah di atas yaitu "open access" atau akses terbuka dimana tidak ada pembatasan penggunaan dan pemanfaatan dari "common resources". Istilah yang kedua adalah "common property" yang diartikan sebagai suatu situasi dimana terdapat kontrol terhadap penggunaan dan pemanfaatan sumberdaya. "Common Property" bukan suatu istilah resmi dan tidak cukup jelas pengertiannya.

Selain itu, Tenurial Sistem dikenal sebagai serangkaian hak-hak (Tenure System Is a Bundle of Rights) yang mana di dalamnya juga terkandung makna kewajiban (obligation). Hal ini didasarkan pada kenyataan lapangan seringkali ditemukan, bahwa hak-hak atas tanah dan sumber-sumber alam ini bersifat multidimensi dan berlapis-lapis. Tidak jarang terjadi, orang atau kelompok orang yang berbeda-beda mempunyai 
hak pada sebidang tanah atau sesuatu sumber alam yang sama. Misalnya pada sebagian dari sistem "kepemilikan" tanah adat, meskipun dikenal hak individu untuk "memiliki" sebidang tanah, namun individu tersebut tidak mempunyai hak untuk mengalihkan tanah tersebut ke orang lain secara bebas tanpa ikut campurnya keluarga dan/atau komunitas dimana tanah itu berada. Pohon-pohon tertentu yang berumur panjang misalnya, punya aturan sistem kepemilikan dan pemanfaatan tertentu yang kadangkadang tidak terkait dengan kepemilikan tanah dimana pohon itu terdapat. Sistem ini dapat berbeda untuk jenis tumbuhan lain yang tumbuh semusim, misalnya. Gambaran di atas merupakan contoh sederhana dimana hak untuk menguasai, memanfaatkan, mengelola, mengalihkan kepemilikan tidak selalu berada pada orang yang sama. Dengan demikian, pengertian "bundle of rights" dalam resource tenure system, memunculkan serangkaian hak tertentu dan pembatasan-pembatasan tertentu atas hak-hak tersebut. Berdasarkan sudut pandang ini, pada setiap tenure system masing-masing hak termaksud setidaknya mengandung tiga komponen hak, yakni:
1. Subjek hak, yang berarti pemangku hak atau pada siapa hak tertentu dilekatkan. Subjek hak bervariasi dapat dari individu, rumah tangga, kelompok, suatu komunitas, kelembagaan sosial ekonomi, bahkan lembaga politik setingkat Negara.

2. Objek hak, yang berupa persil tanah, barang-barang atau juga benda-benda yang tumbuh di atas tanah, barangbarang tambang atau mineral yang berada di dalam tanah atau perut bumi, perairan, kandungan barangbarang atau makhluk hidup dalam suatu kawasan perairan, maupun suatu kawasan atau wilayah udara tertentu. Objek hak termaksud harus dapat dibedakan dengan alat tertentu, dengan objek lainnya. Untuk objek hak berupa suatu persil tanah atau kawasan perairan, batas-batasnya dapat diberi suatu simbol. Objek hak bisa bersifat total dapat juga parsial. Misalnya, seseorang yang mempunyai hak atas pohon tertentu, tidak dengan sendirinya mempunyai hak atas tanah dimana pohon itu berdiri.

3. Jenis haknya, setiap hak selalu dapat dijelaskan batasan dari hak tersebut, yang membedakannya dengan hak lainnya. Dalam hal ini jenis-jenis hak merentang dari hak milik, hak sewa, 
hingga hak pakai, dan lain sebagainya, tergantung bagaimana masyarakat yang bersangkutan menentukannya. Setiap jenis hak ini memiliki hubungan khusus dengan kewajiban tertentu yang dilekatkan oleh pihak lain (mulai dari individu lain hingga Negara) dan keberlakuannya dalam suatu kurun waktu tertentu.

Merujuk kembali kepada istilah Inggris bahwa Land tenure system merupakan penguasaan hak atas tanah, maka jika dikaji kepada ketentuan Undang-Undang Nomor 5 Tahun 1960 tentang Peraturan Dasar Pokok-pokok Agraria, land tenure system tersebut diatur dalam Pasal 16 UUPA, yaitu terdiri dari: (1) Hak Milik, (2) Hak Guna Usaha; (3) Hak Guna Bangunan; (4) Hak Pakai; (5) Hak Sewa; (6) Hak Membuka Tanah; (7) Hak Memungut Hasil Hutan; dan (8) Hak-hak lain yang tidak termasuk dalam hak-hak atas tanah sebelumnya yang akan ditetapkan dengan undang-undang dan sifatnya sementara sebagaimana disebutkan dalam Pasal 53 UUPA, yaitu: (1) Hak Gadai; (2) Hak Usaha Bagi Hasil; (3) Hak Menumpang; dan (4) Hak Sewa Tanah Pertanian.
Diantara hak-hak atas tanah sebagaimana disebutkan di dalam Pasal 16 UUPA, salah satu diantaranya adalah Hak Milik. Perkataan hak milik berasal dari bahasa Arab al haqq dan al milk. Secara etimologis al haqq artinya milik, ketetapan dan kepastian. Adapun Al milk diartikan sebagai penguasaan terhadap sesuatu yang dimiliki (harta). Hubungan seseorang dengan hartanya, menjadikan orang tersebut memiliki kekuasaan khusus terhadap harta tersebut, yaitu melakukan tindakan hukum terhadap harta itu. ${ }^{18}$

Hak milik menurut Lili Rasjidi adalah: "Hubungan seseorang dengan suatu benda yang membentuk hak pemilikan terhadap benda tersebut". ${ }^{19}$

Kemudian menurut Black's Law Dictionary, hak milik adalah:

"That which is peculiar or power to any person; that which belongs exclusively to one. In the strict legal sense, an aggregate of rights which are guaranteed and protected by government". ${ }^{20}$

Merujuk pada pengertian hak milik menurut Black's Law Dictionary, kata

18 Abdul Azis Dahlan, EnsiklopediHukum Islam, Ichtiar Baru Van Hoeve, Jakarta, 2001, hlm. 1177.

19 Lili Rasjidi, Filsafat Hukum, Apakah Hukum Itu?, Cetakan Keempat, Remadja Karya, Bandung, 1988, hlm. 85.

20 Black, H.C., Black's Law Dictionary, Edisi Keenam, West Publishing Co, St. Paul, 1990, hlm. 1216. 
person tersebut, meskipun secara umum diartikan sebagai seseorang (a human being), tetapi dapat pula suatu organisasi atau kumpulan orang-orang (labor organization, partnerships, associations, corporations, legal representatives, trustees, trustees in bankruptcy, or receivers).

Mengingat yang dapat mempunyai hak milik itu bukan hanya subjek hukum orang, tetapi juga badan hukum, maka batasan hak milik yang dianggap tepat adalah hubungan antara subjek hukum dan benda, yang memberikan wewenang kepada subjek hukum untuk mendayagunakan dan/atau mempertahankan benda tersebut dari tuntutan pihak lain. ${ }^{21}$

Adapun pengertian Hak Milik menurut Pasal 20 Undang-Undang Nomor 5 Tahun 1960 Tentang UUPA adalah: "Hak turun temurun, terkuat, dan terpenuh, yang dapat dipunyai orang atas tanah, dengan mengingat fungsi sosial sebagaimana diatur dalam Pasal 6 UUPA".

Sesuai dengan memori penjelasan UUPA bahwa pemberian sifat terkuat dan terpenuh, tidak berarti bahwa hak itu merupakan hak yang mutlak tidak

21 Darji Darmodiharjo dan Shidarta, Pokokpokok Filsafat Hukum, Apa dan Bagaimana Filsafat Hukum Indonesia, PT. Gramedia, Jakarta, 2004, hlm. 186. terbatas, dan tidak dapat diganggu gugat, sebagaimana hak eigendom dalam pengertian aslinya, karena sifat tersebut bertentangan dengan sifat hukum adat dan fungsi sosial. Arti terkuat dan terpenuh dari hak milik adalah untuk membedakan dengan Hak Guna Usaha (HGU), Hak Guna Bangunan (HGB), Hak Pakai (Hak Pakai), dan hak-hak lainnya. Kemudian yang dimaksud dengan Hak Milik yang bersifat turun temurun, artinya hak itu dapat diwariskan terus menerus, dialihkan kepada orang lain tanpa perlu diturunkan derajat haknya. Hak Milik pun memiliki kekhasan karena tidak dibatasi oleh waktu dan diberikan untuk waktu yang tidak terbatas lamanya, yaitu selama hak milik masih diakui.

Adapun makna fungsi sosial dalam UUPA, menurut A.P. Parlindungan bahwa: "Di atas tanah seseorang terkandung hak orang lain, sehingga sekaligus dalam rumusan Pasal 20 UUPA disebutkan dengan mengingat ketentuan Pasal 6 UUPA tentang fungsi sosialnya dalam satu nafas". ${ }^{22}$ Selain itu, secara eksplisit point II angka 4 Penjelasan UUPA, menyebutkan bahwa fungsi sosial, artinya apapun yang ada

22 A.P. Parlindungan, Komentar Atas Undangundang Pokok Agraria, Mandar Maju, Bandung, 1993, hlm. 124-125. 
pada seseorang tidak dapat dibenarkan, bahwa tanahnya itu akan dipergunakan (atau tidak dipergunakan semata-mata untuk kepentingan pribadinya, apalagi menimbulkan kerugian bagi masyarakat.

Dalam pelaksanaannya, hal yang prinsip dalam fungsi sosial adalah kepentingan perseorangan tidak terdesak sama sekali oleh kepentingan umum. Kepentingan masyarakat dan perorangan harus saling mengimbangi, sehingga pada gilirannya akan tercapai kebahagiaan bagi seluruh rakyatnya sebagaimana disebutkan dalam Pasal 2 ayat (3) UUPA, yang berbunyi sebagai berikut:

"Wewenang yang bersumber pada hak menguasai dari negara tersebut pada ayat (2) pasal ini digunakan untuk mencapai sebesar-besar kemakmuran rakyat dalam arti kebangsaan, kesejahteraan, dan kemerdekaan dalam masyarakat dan negara hukum Indonesia yang merdeka, berdaulat, adil, dan makmur".

Bahkan berbeda dengan konsep hukum barat mengenai hak eigendom tersebut, amanat UUPA sehubungan dengan makna fungsi sosial itu membebankan kewajiban kepada pemiliknya untuk memelihara tanahnya dengan sebaik-baiknya, agar bertambah kesuburannya dan dapat dicegah kerusakannya. Kewajiban untuk memelihara tidak saja dibebankan kepada pemiliknya atau pemegang hak, melainkan menjadi beban setiap orang, badan hukum, atau instansi yang mempunyai hubungan hukum dengan tanah itu, dengan memperhatikan kepentingan ekonomi lemah, sebagaimana disebutkan dalam Pasal 15 UUPA.

\section{B. Hak dan Kewajiban Pemerintah} Sebagai Pembuat Kebijakan Land Tenure System dengan Hak dan Kewajiban Masyarakat yang Objek Tanahnya Dikenal Kebijakan Land

\section{Tenure System}

Pearce dan Turner dalam Iqbal dan Sumaryanto, mengemukakan beberapa metode pengendalian alih fungsi lahan, diantaranya melalui Land Tenure System, yaitu salah satu cara pengendalian alih fungsi lahan pertanian yang dilakukan oleh pemerintah sebagai pihak yang memiliki kewenangan/ kebijakan melalui penyempurnaan sistem aturan jual beli lahan serta pola penguasaan lahan yang ada pada masyarakat petani guna mendukung upaya ke arah mempertahankan keberadaan lahan pertanian. $^{23}$ Land

23 Muhammad Iqbal, dan Sumaryanto, Strategi Pengalihan alih Fungsi Lahan Pertanian Bertumpu Pada Partisipasi Masyarakat, Pusat Analisis Ekonomi dan Kebijakan Pertanian, Jakarta, 2007, hlm. 173. 
Tenure System sebagai salah satu strategi yang dapat dilakukan pemerintah guna mencegah alih fungsi lahan pertanian dengan mengikutsertakan partisipasi masyarakat, memiliki konsekuensi adanya hak dan kewajiban kepada para pihak secara timbal balik.

Pemerintah sebagai pembuat kebijakan dalam melindungi lahan pertanian pangan berkelanjutan melalui land tenure system, memiliki kewajiban menjamin konservasi tanah dan air yang dilakukan sesuai dengan ketentuan peraturan perundang-undangan, yang di dalamnya meliputi: (1) perlindungan sumber daya lahan dan air; (2) pelestarian sumber daya lahan dan air; (3) pengelolaan kualitas lahan dan air; dan (4) pengendalian pencemaran. Kemudian, pemerintahpun berkewajiban melakukan pembinaan terhadap masyarakat petani yang terkena kebijakan land tenure system, seperti: (1) melakukan koordinasi perlindungan; (2) sosialisasi peraturan perundang-undangan; pemberian bimbingan, supervisi, dan konsultasi; (4) pendidikan, pelatihan dan penyuluhan; (5) penyebarluasan informasi kawasan pertanian pangan berkelanjutan dan lahan pertanian pangan berkelanjutan; dan/atau (6) peningkatan kesadaran dan tanggung jawab masyarakat. ${ }^{24}$ Selaras dengan pandangan yang disampaikan oleh Pearce and Turner dalam Iqbal dan Sumaryanto bahwa keberhasilan penggunaan metode Land Tenure System tidak dapat dijalankan secara sendiri, tetapi harus didukung oleh metodemetode lainnya yaitu metode Regulation dan Incentive and Charges yaitu pemberian subsidi atau insentif yang diberikan pemerintah kepada para petani yang dapat meningkatkan kualitas lahan yang dimilikinya, seperti pemberian insentif pajak berupa keringanan pembayaran Pajak Bumi dan Bangunan yang menarik bagi petani yang mempertahankan keberadaan lahan pertaniannya, serta memberikan sarana dan prasarana yang mendukung peningkatan hasil pertaniannya. $^{25}$ Selain itu, ada pengembangan infrastruktur pertanian, pembiayaan penelitian dan pengembangan benih dan varietas unggul; kemudahan dalam mengakses informasi dan teknologi, penyediaan sarana dan prasarana produksi pertanian, jaminan

\footnotetext{
24 Anita Kamilah dan Yuyun Yulianah, Model Land Tenure System Dalam Melindungi Lahan Pertanian Pangan Berkelanjutan, Luaran Penelitian Hibah Bersaing Kementerian Riset dan Teknologi Pendidikan Tinggi, hlm. 2016.

25 Muhammad Iqbal, dan Sumaryanto, Strategi Pengalihan alih Fungsi Lahan Pertanian Bertumpu Pada Partisipasi Masyarakat, Ibid., hlm. 173.
} 
penerbitan sertifikat bidang tanah pertanian pangan melalui pendaftaran tanah secara sporadik dan sistematik; dan/atau penghargaan bagi petani berprestasi tinggi.

Kewajiban masyarakat pemilik lahan yang terkena kebijakan land tenure system yaitu: (1) Memanfaatkan tanah sesuai peruntukan; (2) Mencegah kerusakan irigasi sesuai dengan ketentuan peraturan perundang-undangan, (3) Menjaga dan meningkatkan kesuburan tanah; (4) Mencegah kerusakan lahan; (5) Memelihara kelestarian lingkungan; serta (6) Tidak melakukan pengalihan tanah kepada pihak lain.

\section{PENUTUP}

A. Implementasi Konsep Land Tenure System dalam Melindungi Lahan

\section{Pertanian Pangan Berkelanjutan}

Perlindungan lahan pertanian pangan berkelanjutan merupakan sistem dan proses dalam merencanakan dan menetapkan, mengembangkan, memanfaatkan dan membina, mengendalikan dan mengawasi lahan pertanian pangan dan kawasannya secara berkelanjutan, yang dapat dilakukan melalui Land Tenure System, yaitu salah satu cara pengendalian alih fungsi lahan pertanian

yang dilakukan oleh pihak yang memiliki kewenangan melalui penyempurnaan sistem aturan jual beli lahan serta pola penguasaan lahan yang ada guna mendukung upaya ke arah mempertahankan keberadaan lahan pertanian dengan mengikutsertakan partisipasi masyarakat. Namun demikian, keberhasilan penggunaan metode Land Tenure System tidak dapat dijalankan secara sendiri, tetapi harus didukung oleh metode-metode lainnya yaitu metode Regulation yaitu suatu cara pencegahan alih fungsi lahan pertanian, dimana pengambil kebijakan menetapkan sejumlah aturan dalam pemanfaatan lahan yang ada. Berdasarkan pertimbangan teknis, ekonomis, dan sosial, pengambil kebijakan melakukan pewilayahan (zoning) terhadap lahan yang ada serta kemungkinan bagi proses alih fungsi, melalui mekanisme perizinan yang jelas dan transparan dengan melibatkan semua pemangku kepentingan yang ada dalam proses alih fungsi lahan. Selain itu, melalui metode incentive and charges adalah pemberian subsidi atau insentif yang diberikan pemerintah kepada para petani yang dapat meningkatkan kualitas lahan yang dimilikinya, serta pemberian insentif pajak yang menarik bagi petani yang mempertahankan keberadaan lahan 
pertaniannya, serta memberikan sarana dan prasarana yang mendukung peningkatan hasil pertaniannya.

\section{B. Kedudukan Land Tenure System}

\section{Dalam Hukum Agraria Nasional}

Land tenure system merupakan penguasaan hak atas tanah, dimana menurut Pasal 16 UUPA, ada beberapa macam penguasaan hak atas tanah salah satunya adalah hak milik, sebagaimana diatur dalam Pasal 20 UUPA yaitu: "Hak turun temurun, terkuat, dan terpenuh, yang dapat dipunyai orang atas tanah, dengan mengingat fungsi sosial sebagaimana diatur dalam Pasal 6 UUPA". Adapun makna fungsi sosial dalam UUPA, artinya apapun yang ada pada seseorang tidak dapat dibenarkan, bahwa tanahnya itu akan dipergunakan (atau tidak dipergunakan semata-mata untuk kepentingan pribadinya, apalagi menimbulkan kerugian bagi masyarakat). Dilandasi oleh fungsi sosial tersebut, melalui konsep land tenure system ini, pemerintah dapat melakukan upaya melindungi lahan pertanian pangan berkelanjutan, melalui pengaturan pola jual beli serta pengaturan penguasaan lahan, dimana pemilik lahan meskipun memiliki hak penuh atas tanahnya tetapi guna kepentingan perlindungan lahan pertanian pangan berkelanjutan, pemerintah memiliki kebijakan terhadap pemilik tanah untuk tidak mengalihkan tanahnya kepada pihak ketiga.

Penerapan fungsi sosial pada konsep land tenure system itu sendiri selaras dengan pemahaman bahwa Tenurial Sistem dikenal sebagai serangkaian hak-hak (Tenure System Is a Bundle of Rights) yang mana di dalamnya juga terkandung makna kewajiban (obligation)

\section{Hak dan Kewajiban Pemerintah maupun Masyarakat Petani dalam Melindungi Lahan Pertanian Pangan Berkelanjutan melalui \\ Land Tenure System}

1. Pemerintah sebagai pemilik kebijakan land tenure system memiliki kewajiban yaitu: menjamin konservasi tanah dan air yang dilakukan sesuai dengan ketentuan peraturan perundang-undangan, yang di dalamnya meliputi: perlindungan sumber daya lahan dan air; pelestarian sumber daya lahan dan air; pengelolaan kualitas lahan dan air; dan pengendalian pencemaran. Kemudian, pemerintahpun berkewajiban melakukan pembinaan terhadap masyarakat petani yang terkena kebijakan land tenure system, seperti: melakukan koordinasi 
perlindungan; sosialisasi peraturan perundang-undangan; pemberian bimbingan, supervisi, dan konsultasi; pendidikan, pelatihan dan penyuluhan; penyebarluasan informasi kawasan pertanian pangan berkelanjutan dan lahan pertanian pangan berkelanjutan; dan/atau peningkatan kesadaran dan tanggung jawab masyarakat, serta pemberian insentif salah satu diantaranya yaitu: keringanan pembayaran Pajak Bumi dan Bangunan serta jaminan penerbitan sertifikat bidang tanah pertanian pangan melalui pendaftaran tanah secara sporadik dan sistematik.

2. Kewajiban masyarakat pemilik lahan yang terkena kebijakan land tenure system yaitu: memanfaatkan tanah sesuai peruntukan; mencegah kerusakan irigasi sesuai dengan ketentuan peraturan perundangundangan, menjaga dan meningkatkan kesuburan tanah; mencegah kerusakan lahan; memelihara kelestarian lingkungan; serta tidak melakukan pengalihan tanah kepada pihak lain. 


\section{DAFTAR PUSTAKA}

\section{A. Buku}

Abdul Azis Dahlan, Ensiklopedi Hukum Islam, Ichtiar Baru Van Hoeve, Jakarta, 2001.

Anita Kamilah dan Yuyun Yulianah, Model Land Tenure System Dalam Melindungi Lahan Pertanian Pangan Berkelanjutan, Luaran Penelitian Hibah Bersaing Kementerian Riset dan Teknologi Pendidikan Tinggi, 2016.

Black, H.C., Black's Law Dictionary, Edisi Keenam, West Publishing Co, St. Paul, 1990.

Bruce, JW., Review Of Tenure Terminology. Tenure Brief No. 1. University of Wisconsin-Madison. USA, 1998.

FAO., 1989, Sustainable Development and Natural Resources Management. Twenty-Fifth Conference, Paper C 89/2 simp 2, Food and Agriculture Organization, Rome, 1989.

Lili Rasjidi, Filsafat Hukum, Apakah Hukum Itu?, Cetakan Keempat, Remadja Karya, Bandung, 1988.

Muhammad Iqbal, dan Sumaryanto, Strategi Pengalihan alih Fungsi Lahan Pertanian Bertumpu Pada Partisipasi Masyarakat, Pusat Analisis Ekonomi dan Kebijakan Pertanian, Jakarta, 2007.

Nana Apriyana, Kebijakan Pengendalian Konversi Lahan Pertanian Dalam Rangka Mempertahankan
Ketahanan Pangan nasional, Studi kasus pulau Jawa, Kementerian Perencanaan Pembangunan Nasional/Badan Perencana Pembangunan Nasional, Jakarta, 2010.

Rustiadi, E dan W. Reti, Urgensi Lahan Pertanian Pangan Abadi dalam Perspektif Ketahanan Pangan, dalam Arsyad, S dan E. Rustiadi (Ed), Penyelamatan tanah, Air dan Lingkungan. Crestpent Press dan Yayasan Obor Indonesia, 2008.

Wan. A. Hirawan, Kajian Hukum Normatif dan Sosiologi Pembentukan Dinas Pertanahan Kabupaten Sukabumi, Badan Pendidikan dan Pelatihan Pemerintah Kabupaten Sukabumi, 2006.

\section{B. Peraturan Perundang-Undangan}

Undang-Undang Dasar Negara Republik Indonesia tahun 1945;

Undang-Undang Nomor 41 Tahun 2009 tentang Perlindungan Lahan Pertanian Pangan Berkelanjutan

Undang-Undang Nomor 5 Tahun 1960 tentang Peraturan Dasar Pokokpokok Agraria.

\section{Jurnal, Artikel, Makalah, Majalah, Koran, Internet, dan Lain-lain.}

Irawan, B., Konversi Lahan Sawah: Potensi Dampak, Pola Pemanfaatannya dan Faktor 
Determinan. Jurnal Forum

Penelitian Agro Ekonomi, 2005.

Nasional Multifungsi Lahan Sawah. 2001.

Nurmanaf, A.R, H. Mayrowani, dan E. Jamal, Evaluasi Sosial Ekonomi Multifungsi Lahan Sawah.

Prosiding Seminar 